\title{
Structure and Electrical Properties of Fe-Mn-Co-O Spinel
}

\author{
A. KRUK ${ }^{a, *}$ AND T. BRYLEWSKI ${ }^{b}$ \\ ${ }^{a}$ Pedagogical University, Institute of Technology, Podchorążych 2, 30-084 Krakow, Poland \\ ${ }^{b}$ AGH University of Science and Technology, Faculty of Materials Science and Ceramics, \\ al. A. Mickiewicza 30, 30-059 Krakow, Poland
}

(Received August 31, 2018; in final form February 22, 2019)

\begin{abstract}
Sub micro-sized $\mathrm{Fe}_{0.1} \mathrm{Mn}_{1.45} \mathrm{Co}_{1.45} \mathrm{O}_{4}$ powders were obtained using the sol-gel method with EDTA as a complexing agent. The sinters obtained from these powders were characterized by means of scanning electron microscopy, X-ray fluorescence, the Mössbauer spectroscopy, X-ray diffraction, and the 2-probe 4-point direct current method. The X-ray diffraction investigation of the sinter revealed that only the cubic phase had formed. Scanning electron microscopy showed that the sample was dense and exhibited a certain porosity. The addition of iron ions to the $\mathrm{Mn}_{1.5} \mathrm{Co}_{1.5} \mathrm{O}_{4}$ spinel reduced the electrical conductivity of the obtained sinter from $c a .60$ to over $50 \mathrm{~S} / \mathrm{cm}$ at $973 \mathrm{~K}$. The Mössbauer studies showed the full incorporation of iron into the lattice structure of $\mathrm{Mn}_{1.5} \mathrm{Co}_{1.5} \mathrm{O}_{4}$. In conclusion, the iron-doped spinel appears to be suitable for the surface modification of ferritic stainless steel substrates used in solid oxide fuel cells interconnects.
\end{abstract}

DOI: 10.12693/APhysPolA.135.439

PACS/topics: sol-gel, SOFC, electrical conductivity, Mössbauer spectroscopy, microstructure

\section{Introduction}

Intermediate-temperature solid oxide fuel cells (IT-SOFCs) are eco-friendly and high efficient devices that are likely to replace traditional energy generators at some point in the future. They produce electricity without combustion by combining oxygen and hydrogen to produce clean water and heat. Their operation is based on the conversion of chemical energy to electrical current. The ceramic elements of a typical IT-SOFC cell include an anode, electrolyte, and cathode, whereas individual cells are combined to form a stack, which allows SOFCs to achieve a high electrical power density and subsequently, a high output. A metallic interconnect is placed between cells. This component plays several key roles - it connects individual cells, distributes fuel and air, delivers electric current to external circuits, and acts as a support element for the entire fuel cell structure. In the case of IT-SOFCs, numerous types of stainless steel have been considered as interconnect materials. Investigations have focused on chromium-rich steel because of its good electrical conductivity, durability and low cost of fabrication $[1,2]$. Nevertheless, chromium evaporates from the steel core to the remaining parts of SOFC at a rapid rate, subsequently poisoning the electrode materials. Solutions to this problem include the deposition of thick or thin layers of $\mathrm{Mn}-\mathrm{Co}$ oxide spinel on the surface of the interconnector [3].

This type of spinel is a promising conductingprotective material, since it exhibits good electrical conductivity and high density, is a good barrier against the diffusion of chromium ions, and the cost of the starting materials required to obtain is not overly high [4].

*corresponding author; e-mail: andrzej.kruk@up.krakow.pl
Its electric conductivity $(\approx 0.05 \mathrm{~S} / \mathrm{cm})$ is several times higher than that of chromium $(\approx 0.01 \mathrm{~S} / \mathrm{cm})$. The physicochemical properties of $\mathrm{Mn}-\mathrm{Co}$ spinel can be improved further using different types of additives, including $\mathrm{Y}, \mathrm{Cu}$, and $\mathrm{Ni}$ [5-9]. Gavrilov et al. [5] obtained $\mathrm{Mn}-\mathrm{Co}-\mathrm{O}(\mathrm{MC})$ and $\mathrm{Mn}-\mathrm{Co}-\mathrm{Y}-\mathrm{O}(\mathrm{MCYO})$ layers using coatings deposited via magnetron sputtering on ferritic stainless steel. This modification made it possible to reduce the area specific resistance (ASR, Eq. (1)) for the MCYO coating from 7.5 to $5.8 \mathrm{~m} \Omega \mathrm{cm}^{2}$ within the first $200 \mathrm{~h}$ of testing; the ASR then increased to $15 \mathrm{~m} \Omega \mathrm{cm}^{2}$ within $4800 \mathrm{~h}$. In another study, Masi et al. [6] doped $\mathrm{Mn}-\mathrm{Co}-\mathrm{O}$ powders with $\mathrm{Fe}, \mathrm{Cu}$, and both of these elements at the same time via synthesis by means of a solid-state reaction. After the substitution of Co with $\mathrm{Fe}$, a conductivity at $1073 \mathrm{~K}$ was about $51 \mathrm{~S} / \mathrm{cm}$ and $36 \mathrm{~S} / \mathrm{cm}$ for the $\mathrm{MnCo}_{1.8} \mathrm{Fe}_{0.2} \mathrm{O}_{4}$ and $\mathrm{MnCo}_{1.6} \mathrm{Fe}_{0.4} \mathrm{O}_{4}$ samples, respectively. Co-doping with both $\mathrm{Co}$ and $\mathrm{Cu}$ significantly increased conductivity to a level of over $80 \mathrm{~S} / \mathrm{cm}$. Using the sol-gel method followed by calcination at $1073 \mathrm{~K}$, Mah et al. [7] fabricated $(\mathrm{Cu}, \mathrm{Mn}, \mathrm{Co})_{3} \mathrm{O}_{4}$ ceramics with an electrical conductivity of over $110 \mathrm{~S} / \mathrm{cm}$. The activation energy of electrical conduction measured for this spinel was $c a .0 .4 \mathrm{eV}$. Chouaya et al. [8] demonstrated the possibility of obtaining $\mathrm{Co}_{2} \mathrm{Mn}_{1-x} \mathrm{Bi}_{x} \mathrm{O}_{4}$ with good physicochemical properties and dense microstructure. These samples were obtained via the sol-gel method with the citrate process.

In recent years, the possibility of improving the electrical conductivity of $(\mathrm{Mn}, \mathrm{Co})_{3} \mathrm{O}_{4}$ as a result of a partial substitution of iron in place of cobalt has been studied intensively [9]. This is due to the fact that the thermal expansion coefficient (TEC) of doped $\mathrm{MnCo}_{2} \mathrm{O}_{4}$ oxide closely matches the TEC of other SOFC components; this is especially true of the Crofer 22 APU ferritic steel, which is currently considered one of the best interconnect materials for IT-SOFC fuel cell stacks designed 
for operation at temperatures not higher than $1073 \mathrm{~K}$. A review of the literature shows that the addition of $\mathrm{Fe}$ ions to spinels with the composition of $\mathrm{MnCo}_{2} \mathrm{O}_{4}$ and $\mathrm{Mn}_{1.5} \mathrm{Co}_{1.5} \mathrm{O}_{4}$ may on the one hand worsen, and on the other improve their electrical conductivity. The results largely depends on the powder synthesis method and the conditions applied in the thermal treatment of the sinters. Additional research is necessary to better understand the effect of iron on the transport properties of the $\mathrm{MnCo}_{2} \mathrm{O}_{4}$ or $\mathrm{Mn}_{1.5} \mathrm{Co}_{1.5} \mathrm{O}_{4}$ spinels.

In this work, $\mathrm{Fe}_{0.1} \mathrm{Mn}_{1.45} \mathrm{Co}_{1.45} \mathrm{O}_{4}$ was synthesized via the sol-gel method with EDTA as a complexing agent. In addition, the effect of replacing $\mathrm{Mn}$ and $\mathrm{Co}$ in $\mathrm{Mn}_{1.5} \mathrm{Co}_{1.5} \mathrm{O}_{4}$ with $\mathrm{Fe}$ on the structural and electrical properties was investigated.

\section{Experiment}

\subsection{Sample preparation}

$\mathrm{Fe}_{0.1} \mathrm{Mn}_{1.45} \mathrm{Co}_{1.45} \mathrm{O}_{4}$ was obtained via the sol-gel method with EDTA as an agent that complexed metal cations in an aqueous solution (often referred to as EDTA gel processes). The idea of using EDTA gel processes is to reduce the concentration of free metal ions in the precursor solution. The following starting materials were used to prepare the gel precursor: iron(III) nitrate hexahydrate $\mathrm{Fe}\left(\mathrm{NO}_{3}\right)_{3} \cdot 6 \mathrm{H}_{2} \mathrm{O}$ (Sigma-Aldrich; 99.9\%), manganese(III) nitrate hexahydrate $\mathrm{Mn}\left(\mathrm{NO}_{3}\right)_{3} \cdot 6 \mathrm{H}_{2} \mathrm{O}$ (Sigma-Aldrich; $\geq 99.9 \%$ ), and cobalt(III) nitrate hexahydrate $\mathrm{Co}\left(\mathrm{NO}_{3}\right)_{3} \cdot 6 \mathrm{H}_{2} \mathrm{O}$ (Sigma-Aldrich, 99.8\%), ethylenediaminetetraacetic acid $\left(\mathrm{C}_{10} \mathrm{H}_{16} \mathrm{~N}_{2} \mathrm{O}_{8}\right.$, Aldrich; 99.995\%). Nitrate salts with a known dry weight were dissolved in distilled water to prepare nitrate solutions of iron, manganese, and cobalt with concentrations of $0.302,0.8279$, and $0.3861 \mathrm{~mol} / \mathrm{dm}^{3}$, respectively. In the next stage of gel precursor preparation, the above-mentioned solutions were mixed at molar ratios corresponding to the nominal composition of $\mathrm{Fe}_{0.1} \mathrm{Mn}_{1.45} \mathrm{Co}_{1.45} \mathrm{O}_{4}$. To this nitrate solution, a $0.1 \mathrm{M}$ EDTA solution was added in such an amount as to obtain one mole of complexing agent per one mole of metal cation, and the resulting solution was mixed. The $\mathrm{pH}$ of 8 was maintained to prevent the precipitation of salt. The aqueous solution was heated up to $923 \mathrm{~K}$ and burned, which yielded the required powder.

The obtained powder was calcinated in air at $973 \mathrm{~K}$ for $8 \mathrm{~h}$, and then ground in an agate mortar with anhydrous ethanol. After drying at room temperature, the material was biaxially pressed into green bodies under a pressure of $70 \mathrm{MPa}$. The green bodies were additionally compacted via cold isostatic pressing (CIP) under $250 \mathrm{MPa}$, and then sintered for $10 \mathrm{~h}$ in air at $1473 \mathrm{~K}$.

\subsection{Methodology}

A Bruker D8 Advance XRD diffractometer with the LYNXEYE (1D) detector was used to analyze the phase composition of the sample. XRD patterns were recorded over the angle range of $10-90^{\circ}$, with a step size of $0.03^{\circ}$
$(2 \Theta)$ and with source $\mathrm{Cu} K_{\alpha}=0.15406 \mathrm{~nm}$. Qualitative phase analysis was conducted with the use of the DIFFRAC.SUITE software package. The Rietveld profile refinement and the Scherrer equation were used to obtain information about the lattice parameter and the crystallite size of the sample, respectively.

The chemical composition of the obtained powder was determined via X-ray fluorescence (XRF) performed with the WDXRF Axios mAX spectrometer with an Rh lamp with an output of $4 \mathrm{~kW}$ (PANalytical).

The Hitachi TM 3000 scanning electron microscope was used to examine the morphology of the polished surface of the sample.

Electrical resistance measurements of the sinter were conducted by means of the 2-probe 4-point direct current method, using an external current source. Electrical conductivity studies were performed as function of temperature in the range from 300 to $1073 \mathrm{~K}$, with a current intensity of $0.01 \mathrm{~A}$ and in laboratory air. Both sides of the sinter were covered with $\mathrm{Pt}$ paste (Heraeus). The sample was placed between two-plane Pt electrodes, and the voltage drop was measured under direct current (and with polarity reversal) using the power supply (JOTA, ZS-2002). The current drop for the sample was measured with a digital multimeter (HP 34401) with $0.3 \%$ precision. The temperature was then increased by $50 \mathrm{~K}$ and the sample was equilibrated at this increased temperature for $1 \mathrm{~h}$. The area specific resistance ASR of the studied sample was calculated based on the resistance values using the following formula:

$$
A S R=\frac{R \times S}{2},
$$

where $R$ is the electrical resistance $(\Omega)$, and $S$ is the area of Pt layer $\left(\mathrm{cm}^{2}\right)$.

The absorption of $\mathrm{Fe}_{0.1} \mathrm{Mn}_{1.45} \mathrm{Co}_{1.45} \mathrm{O}_{4}$ was measured via the Mössbauer spectroscopy performed with the RENO MsAa-3 device at room temperature; the radiation of the ${ }^{57} \mathrm{Fe}$ isotope was utilized with $14.4 \mathrm{keV}$ transmissions and random absorbers. The MsAa-3 spectrometer was used with 4096 data channels per unfolded spectrum. The Mössbauer spectrometer was calibrated using a Michelson-Morley interferometer equipped with a $\mathrm{He}-\mathrm{Ne}$ laser. Shifts in the spectrum were analyzed continuously and corrected due to changes in the pressure and ambient temperature. The collected spectra were interpreted using the dedicated Mosgraf 2009 software supplied with the apparatus. The applied gamma radiation had a very narrow frequency range, and subsequently acted as a detector of the effects of the nucleus' interaction with the electromagnetic field of electrons and other atoms through a negligible shift of energy levels in the nucleus [10].

\section{Results and discussion}

It is well-known that the $\mathrm{Mn}_{1.5} \mathrm{Co}_{1.5} \mathrm{O}_{4}$ spinel at room temperature features a dual-phase structure with both cubic and tetragonal phases [11]. In the present 
study, the XRD pattern obtained for the synthesized $\mathrm{Fe}_{0.1} \mathrm{Mn}_{1.45} \mathrm{Co}_{1.45} \mathrm{O}_{4}$ powder (Fig. 1a) revealed only the cubic structure (ICSD \#00-023-1237) with the Fd3m space group and with a mean crystallite size of $D_{X R D}=$ $11 \mathrm{~nm}$. No peaks corresponding to the tetragonal phase were observed (ICSD \#00-018-0409). In the case of the sinter (Fig. 1b), the XRD pattern likewise revealed only a single cubic phase (ICSD \#00-023-1237). A similar result was reported in one of our previous studies, which indicated that the doping of the $\mathrm{Mn}-\mathrm{Co}-\mathrm{O}$ spinel with $\mathrm{Cu}$ can affect phase composition [12]. The lattice parameters and unit cell volumes of the investigated $\mathrm{Fe}_{0.1} \mathrm{Mn}_{1.45} \mathrm{Co}_{1.45} \mathrm{O}_{4}$ sinter and the corresponding data for the cubic phase of the reference $\mathrm{Mn}_{1.5} \mathrm{Co}_{1.5} \mathrm{O}_{4}$ spinel [3] are presented in Table I. The representative (311) peak was used to estimate the parameters. The addition of iron causes both the lattice constant and the
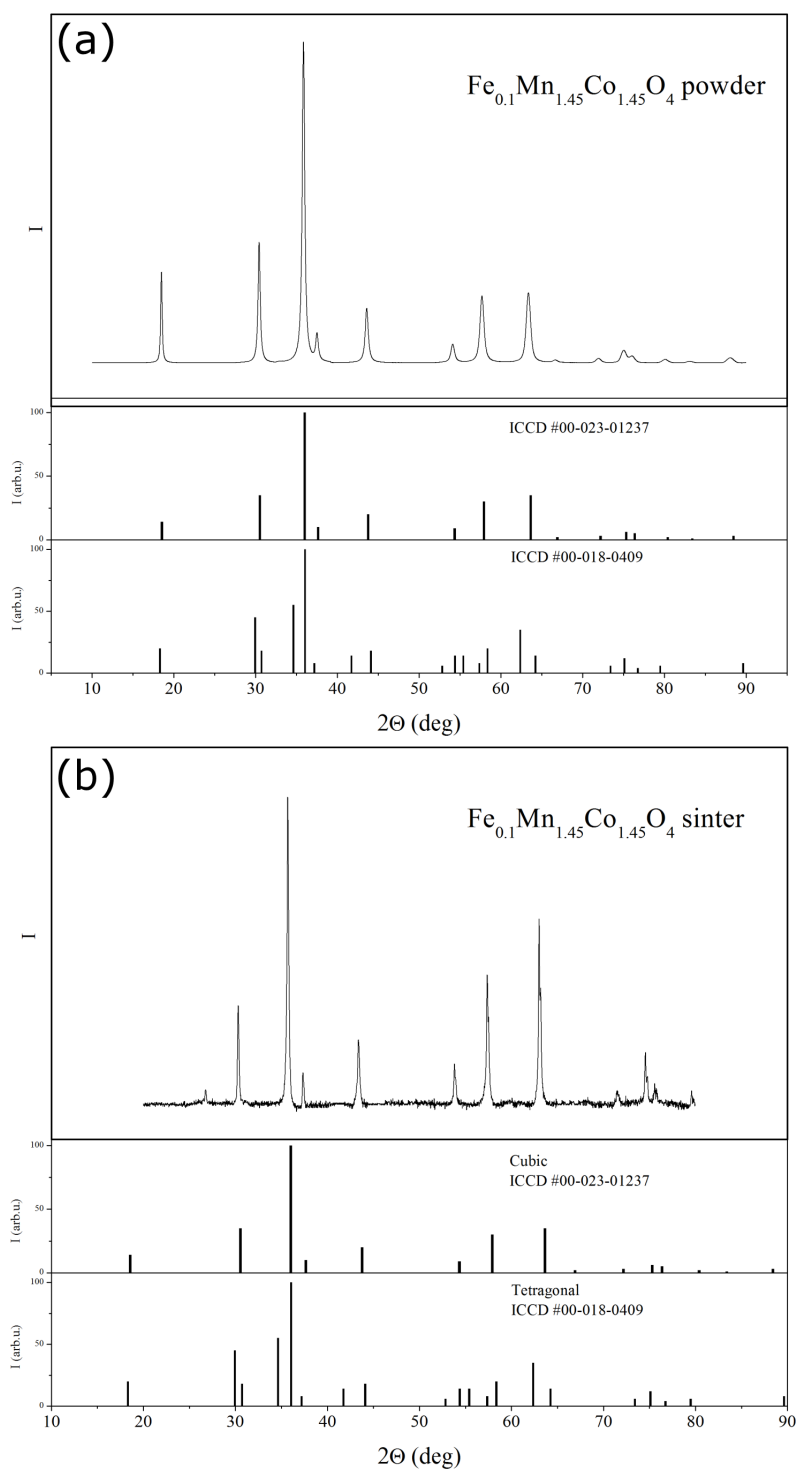

Fig. 1. The XRD pattern of $\mathrm{Fe}_{0.1} \mathrm{Mn}_{1.45} \mathrm{Co}_{1.45} \mathrm{O}_{4}$ powder (a) and the corresponding sinter (b). unit cell volume to increase. It is therefore likely that $\mathrm{Fe}^{3+}$ replaces $\mathrm{Co}^{2+}$ at tetragonal sites in the reference spinel and that the increase in lattice constant is due to charge compensation by $\mathrm{Co}$ and $\mathrm{Mn}$ on the octahedral sites. The results are consistent with those obtained by other investigators [5-8].

TABLE I

Lattice constant and unit cell volume of the $\mathrm{Fe}_{0.1} \mathrm{Mn}_{1.45} \mathrm{Co}_{1.45} \mathrm{O}_{4}$ sinter and the cubic phase of the reference $\mathrm{Mn}_{1.5} \mathrm{Co}_{1.5} \mathrm{O}_{4}$ spinel [3].

\begin{tabular}{c|c|c}
\hline \hline \multicolumn{1}{c|}{ Name } & $\begin{array}{c}\text { Lattice } \\
\text { constant } a[\AA]\end{array}$ & $\begin{array}{c}\text { Unit cell } \\
\text { volume } a^{3}\left[\AA^{3}\right]\end{array}$ \\
\hline $\mathrm{Fe}_{0.1} \mathrm{Mn}_{1.45} \mathrm{Co}_{1.45} \mathrm{O}_{4}$ & 8.29 & 569.72 \\
$\mathrm{Mn}_{1.5} \mathrm{Co}_{1.5} \mathrm{O}_{4}$ (cubic) & 8.12 & 535.39
\end{tabular}

To determine the deviation of the $\mathrm{Fe}_{0.1} \mathrm{Mn}_{1.45} \mathrm{Co}_{1.45} \mathrm{O}_{4}$ powder obtained via EDTA gel processes after $8 \mathrm{~h}$ of calcination in air at $973 \mathrm{~K}$ from its nominal composition, its actual composition was determined using XRF.

The concentrations of manganese, cobalt, and iron in the studied sample are the following: 1.46, 1.43, 0.11 respectively, as determined by means of XRF. These data show that the molar ratios of the metals for the calcinated powder closely reflect the nominal composition.

Figure 2 presents the results of the Mössbauer effect study conducted for the $\mathrm{Fe}_{0.1} \mathrm{Mn}_{1.45} \mathrm{Co}_{1.45} \mathrm{O}_{4}$ powder by means of the transmission technique on ${ }^{57} \mathrm{Fe}$ atomic nuclei at room temperature.

The obtained Mössbauer spectra can be attributed to hyperfine interactions of the atomic nucleus with a quadrupole electric interaction (doublet). The results of this study indicate that iron only occurs as $\mathrm{Fe}^{3+}$ in the same amount in both tetrahedral and octahedral coordination. The obtained spectrum of hyperfine interactions is rather typical of iron-doped spinel.

The morphology of the surface of the $\mathrm{Fe}_{0.1} \mathrm{Mn}_{1.45} \mathrm{Co}_{1.45} \mathrm{O}_{4}$ sinter was examined via SEM

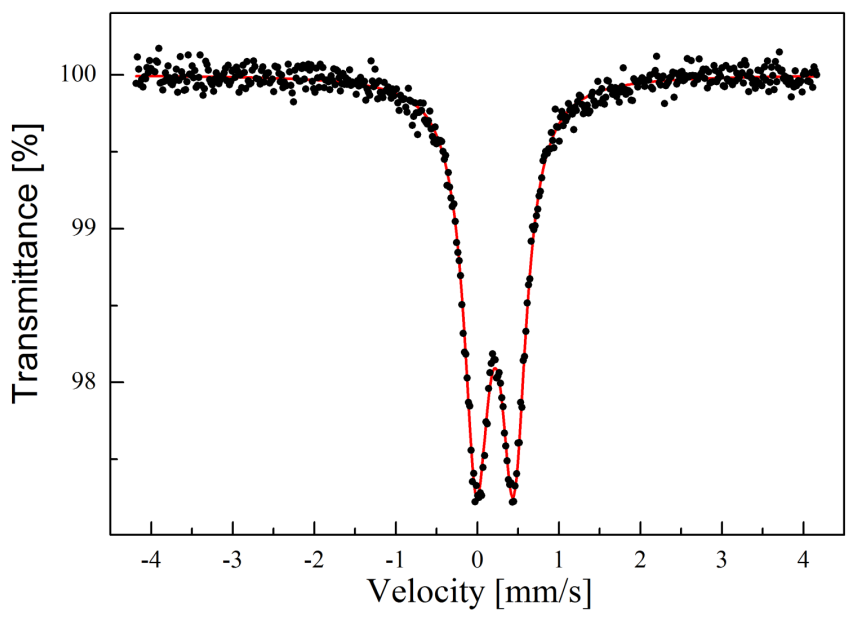

Fig. 2. ${ }^{57} \mathrm{Fe}$ Mössbauer spectra recorded for the $\mathrm{Fe}_{0.1} \mathrm{Mn}_{1.45} \mathrm{Co}_{1.45} \mathrm{O}_{4}$ powder at room temperature. 


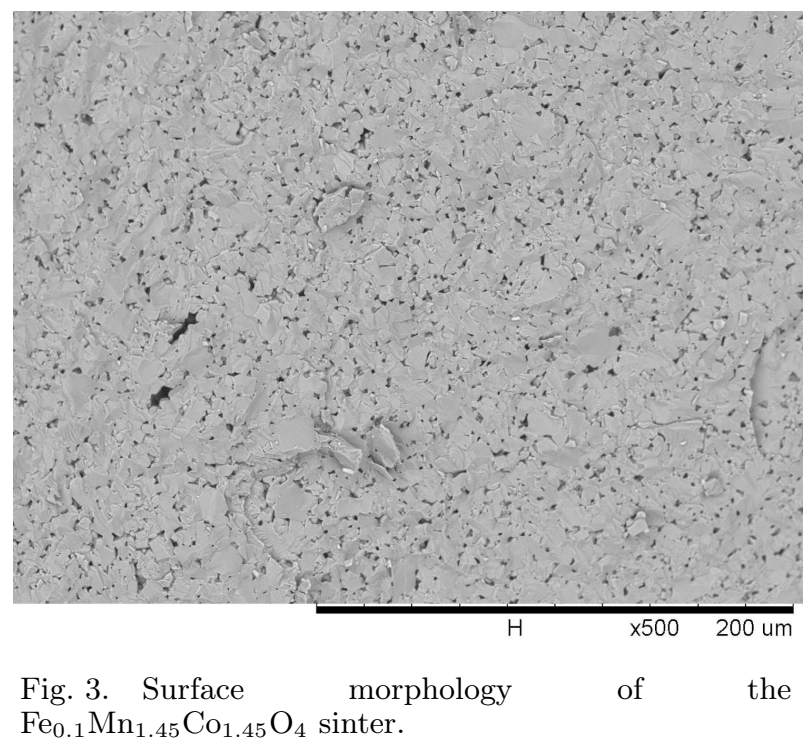

(Fig. 3), which revealed compact grains with a regular shape. Grain size distribution was wide $(1-30 \mu \mathrm{m})$ and one-modal with a maximum of $c a .15 \mu \mathrm{m}$. The majority of grains had a diameter in the range from 5 to $20 \mu \mathrm{m}$. A certain number of pores were found in the grain interiors and at grain boundaries.

To determine the electrical properties of the $\mathrm{Fe}_{0.1} \mathrm{Mn}_{1.45} \mathrm{Co}_{1.45} \mathrm{O}_{4}$ sinter, its electrical conductivity was measured. Figure 4 shows the corresponding Arrhenius plot for the $\mathrm{Fe}_{0.1} \mathrm{Mn}_{1.45} \mathrm{Co}_{1.45} \mathrm{O}_{4}$ sinter and the $\mathrm{Mn}_{1.5} \mathrm{Co}_{1.5} \mathrm{O}_{4}$ sinter as Ref. [3].

The linear character of electrical conductivity is typical for semiconductors with conductivity thermally activated through the hopping of small polarons [8-10]. This conductivity mechanism can be explained by the Arrhenius law, which is expressed by the equation

$$
\sigma T=C \exp \left(E_{a} / k T\right)
$$

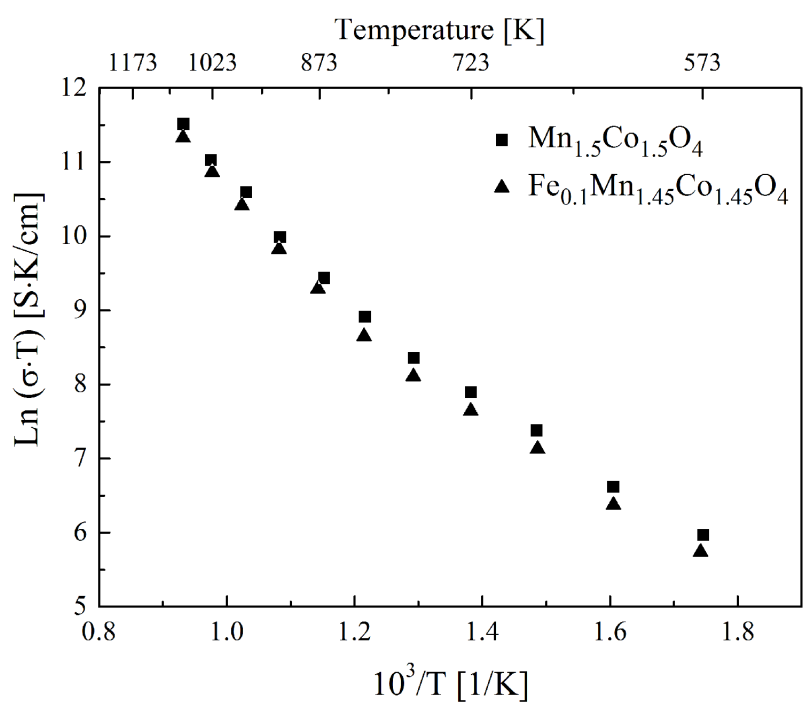

Fig. 4. The Arrhenius plots representing the electrical conductivity of the $\mathrm{Fe}_{0.1} \mathrm{Mn}_{1.45} \mathrm{Co}_{1.45} \mathrm{O}_{4}$ sinter and the $\mathrm{Mn}_{1.5} \mathrm{Co}_{1.5} \mathrm{O}_{4}$ reference sinter [4]. where $\sigma$ - the specific conductivity $\left(\mathrm{S} \mathrm{cm}^{-1}\right), T$ - temperature $(\mathrm{K}), C$ - a material constant containing the carrier concentration term $\left(\mathrm{S} \mathrm{cm}{ }^{-1} \mathrm{~K}\right), E_{a}$ - the activation energy of electrical conduction $(\mathrm{eV})$, and $k$ Boltzmann's constant $\left(8.617 \times 10^{-5} \mathrm{eV} / \mathrm{K}\right)$.

The electrical conductivity of the $\mathrm{Fe}_{0.1} \mathrm{Mn}_{1.45} \mathrm{Co}_{1.45} \mathrm{O}_{4}$ sinter in air was lower than that of undoped spinel. At the temperature of $973 \mathrm{~K}$, which reflects the typical operating temperature of IT-SOFCs, the electrical conductivity values determined for the $\mathrm{Fe}_{0.1} \mathrm{Mn}_{1.45} \mathrm{Co}_{1.45} \mathrm{O}_{4}$ and $\mathrm{Mn}_{1.5} \mathrm{Co}_{1.5} \mathrm{O}_{4}$ spinels were 50 and $61 \mathrm{~S} / \mathrm{cm}$, respectively. The activation energy of electrical conduction in the $\mathrm{Fe}_{0.1} \mathrm{Mn}_{1.45} \mathrm{Co}_{1.45} \mathrm{O}_{4}$ spinel was $0.46 \mathrm{eV}$ for temperatures over $723 \mathrm{~K}$ and $0.75 \mathrm{eV}$ below $723 \mathrm{~K}$. At $723 \mathrm{~K}$, a change in slope of the conductivity curves is observed. These effects have been reported previously for similar spinel compositions $[6,8,9]$. One possible explanation is a change in the prevailing conduction mechanism. Typically, at low temperatures, grain boundaries are considered more conductive than grains and at high temperatures, grains contribute more. As can be seen when this value is compared with the value reported for the $\mathrm{Mn}_{1.5} \mathrm{Co}_{1.5} \mathrm{O}_{4}$ spinel $(0.42 \mathrm{eV})$, the addition of Fe significantly increases the activation energy required for electrical conduction.

Low resistance is one of the requirements for IT-SOFC interconnects materials [1-5]. An electrical conductivity study of both materials indicates that their application should minimize electrical resistance at the electrodeinterconnect interface. The hopping of small polarons is activated by the presence of cations with different valence states at octahedral sites [6-9]. In this instance, the addition of $\mathrm{Fe}$ into $\mathrm{Mn}_{1.5} \mathrm{Co}_{1.5} \mathrm{O}_{4}$ spinel promotes the formation of $\mathrm{Fe}^{3+}$, simultaneously inducing the transition of $\mathrm{Mn}^{2+} / \mathrm{Mn}^{3+}$ and $\mathrm{Mn}^{3+} / \mathrm{Mn}^{4+}$ at octahedral sites [5-9]. Consequently, the hopping activity in the spinel material decreases and so does electrical conductivity [6].

\section{Conclusions}

In the presented work, we studied the structural and electrical properties of the $\mathrm{Fe}_{0.1} \mathrm{Mn}_{1.45} \mathrm{Co}_{1.45} \mathrm{O}_{4}$ compound prepared using the sol-gel method. An exclusively cubic phase composition with the $F d 3 m$ space group was obtained for the powder sample and the corresponding sinter. When compared to the $\mathrm{Mn}_{1.5} \mathrm{Co}_{1.5} \mathrm{O}_{4}$ reference spinel, a increase in the lattice constant was observed after the addition of $\mathrm{Fe}$.

Although the $\mathrm{Mn}_{1.5} \mathrm{Co}_{1.5} \mathrm{O}_{4}$ spinel doped with Fe exhibited a slightly lower electrical conductivity than the reference spinel without the addition of iron, the singlephase composition of the doped sinter makes it a suitable material for the intended application, namely for the modification of IT-SOFC interconnects based on ferritic stainless steels.

\section{Acknowledgments}

The authors are very grateful to Prof. Artur Błachowski, who performed the Mössbauer measurements. 


\section{References}

[1] N. Grünwald, D. Sebold, Y.J. Sohn, N.H. Menzler, R. Vaßen, J. Power Sourc. 363, 185 (2017).

[2] Crofer 22 APU Werkstoffdatenblatt Nr 4146, ThyssenKrupp VDM, 2010.

[3] A. Kruk, M. Stygar, T. Brylewski, K. Przybylski, Archiv. Metall. Mater. 58, 376 (2013).

[4] M. Ustundağ, M. Aslan, Acta Phys. Pol. A 130, 362 (2016).

[5] N.V. Gavrilov, V.V. Ivanov, A.S. Kamenetskikh, A.V. Nikonov, Surf. Coat. Technol. 206, 1252 (2011).

[6] A. Masia, M. Bellusci, S.J. McPhail, F. Padella, P. Reale, J. Hong, R. Steinberger-Wilckens, M. Carlini, Ceram. Int. 43, 2829 (2017).
[7] J.C.W. Mah, A. Muchtar, M.R. Somalu, M.J. Ghazali, J. Raharjo, Ceram. Int. 43, 7641 (2017).

[8] H. Chouaya, M. Smari, I. Walha, E. Dhahri, M.P.F. Graça, M.A. Valente, J. Magn. Magn. Mater. 451, 344 (2018).

[9] V. Miguel-Perez, A. Martinez-Amesti, M.L. Nó, A. Larranaga, M.I. Arriortura, J. Power Sources 243, 419 (2013).

[10] A. Błachowski, K. Ruebenbauer, Acta Phys. Pol. A 115, 636 (2009).

[11] Y.V. Golikov, S.Y. Tubin, V.P. Barkhatov, V.F. Balakirev, J. Phys. Chem. Solids 46, 539 (1985).

[12] T. Brylewski, A. Kruk, M. Bobruk, A. Adamczyk, J. Partyka, P. Rutkowski, J. Power Sourc. 333, 145 (2016). 